\title{
Performance of Electrochemical Oxidation in Treating Textile Dye Wastewater by Stainless Steel Anode
}

\author{
Usha N Murthy, H.B.Rekha, and J.G.Bhavya
}

\begin{abstract}
Electrochemical oxidation for a textile dye wastewater collected from a textile processing industry was investigated in this study using Stainless Steel an anode. Number of batch experiments was run in a laboratory-scale. The results are reported in terms of percentage removal of Chemical Oxygen Demand (COD), Color and variations in BOD/COD ratio for different current densities of 12, 24 and 48 $\mathrm{A} / \mathrm{m}^{2}$. For current densities 12,24 and $48 \mathrm{~A} / \mathrm{m}^{2}$, COD was reduced by $52 \%, 63 \%$ and $71 \%$ respectively; Color was reduced by $41 \%, 55 \%, 77 \%$ respectively. The biodegradability was improved because of the increase BOD/COD ratio from 0.1 to 0.58 . It was observed that increasing the electrolysis time and increased current density bring down the concentration of pollutants. COD removal and energy consumption rates are discussed. Kinetics for COD removal is also discussed. It can be concluded from the results that SS as an anode found to be effective in treating this electrolyte and could be effectively used for pretreatment of textile dye wastewater.
\end{abstract}

Index Terms - COD, Color, Dye, Stainless Steel.

\section{INTRODUCTION}

In general, the wastewater generated from textile industries is found to contain high degree of pollutants with high total Dissolved Solids and suspended solids. The wastewater is highly colored and viscous due to dyestuff and suspended solids respectively. Sodium is the only major cation due to high consumption of sodium salts in processing units, chloride is the major anion found in the wastewater, the concentrations of bicarbonate, sulphate and nitrate are also high. Heavy metals like chromium, iron, lead, zinc, copper, manganese are also present. BOD, COD are also high and $\mathrm{BOD} / \mathrm{COD}$ ratio is between $0.15-0.3$, which indicates the recalcitrant nature of organics present in the wastewater ${ }^{[6]}$.

Color is one of the most important water quality parameter. During the dying process, about $5-20 \%$ of the dye is lost due to its partial adsorption on the fibers. Dyes are manufactured to have high chemical resistance because they are normally chemical species that are very difficult to degrade (aromatic dyes) ${ }^{[2]}$. It damages both aquatic flora and fauna. Furthermore, colored effluents may contain considerable amounts of toxic compounds, especially azo dyes that are known to be highly carcinogenic ${ }^{[4]}$. The removal of dyes is therefore a challenge to both the textile industry and the

Manuscript received Ocotber 9, 2011, revised October 24, 2011. This work was supported in part by the Bangalore University, Bangalore under Grant BUIRF.

Usha N Murthy, Professor, and Smt Rekha H B, Asst. Professor, and J.G.Bhavya, former P.G student, Dept of Civil Engg., UVCE, Bangalore University, Bangalore, Karnataka, India (e-mail:ushanmurthy@yahoo.co.in; rekhahb@gmail.com; bhavyajg@yahoo.com). wastewater treatment facilities. Dyeing wastewater is usually treated by conventional methods such as biological oxidation and adsorption. Because of the large variability of the composition of textile wastewater, most of these traditional methods are becoming inadequate ${ }^{[8]}$.

Recently there has been growing interest towards electrochemical techniques for the treatment of wastewater containing organic pollutants. Two important features of the electrochemical process are converting non-biocompatible organics into biocompatible compounds and oxidation of organics into carbon dioxide and water ${ }^{[6]}$.

\section{THEORIES OF ELECTROCHEMICAL TREATMENT}

A typical electrochemical treatment process consists of electrolytic cell, which uses electrical energy to affect a chemical change. In simplest forms, we can say that, an electrolytic cell consists of two electrodes, anode and cathode, immersed in an electrical conducting solution (the electrolyte), and are connected together, external to the solution, via an electrical circuit which includes a current source and control device. The chemical processes occurring in such cells are oxidation and reduction, taking place at the electrode/electrolyte interface. The electrode at which reduction occurs is referred to as the cathode and conversely, the anode is the electrode at which oxidation processes occur. The current flow in an electrochemical cell is maintained by the flow of electrons resulting from the driving force of the electrical source. In order to allow the current to flow, there must be an electrolyte, which facilitate the flow of current by the motion of its ionic charged species. Type of electrolyte has significant effect on the process in the formation of oxidizing species during the process [5].

Generally, oxidation of organic matter by electrochemical treatment can be classified as direct oxidation at surface of anode and indirect oxidation distant from the anode surf ace; processes are influenced significantly by the anode material. The energy supplied to an electrochemical reactor plays an important role in any electrochemical process. The energy supplied to an electrode undergoes the following steps during the process ${ }^{[3]}$.

1. The electro active particle is transferred to the electrode surface from the bulk solution.

2. The electro active particle is adsorbed on to the surface of the electrode.

3. Electron transfer occurs between the bulk and the electrode.

4. The reacted particle is either transported to the bulk solution (desorption) or deposited at the electrode surface. 


\section{METHODS}

The electrochemical cell consists of an undivided reactor with two parallel electrodes having an inter-electrode gap of $40 \mathrm{~mm}$. The electrochemical cell has a volume of $1000 \mathrm{ml}$. Both anode and cathode were placed vertical and parallel to each other. The electric power required during the electrolysis was provided by a laboratory Dual DC power supply (Textronix 35D, 0-15V, 0-10A). The electrolytic cell was equipped with a magnetic stirrer in order to keep the electrolyte well mixed. The schematic diagram of the experimental setup is shown in Fig. 1 and consists of a borosil glass beaker of 1 lit capacity as the electrolytic cell. In this study, individual effects of electrode surface area and applied current on decolorization rate and COD removal were quantified. Commercially available Stainless Steel (SS) of 5 $\mathrm{cm} * 5 \mathrm{~cm}$ dimension was used as anode and cathode. The electrolysis was carried out under galvanostaatic conditions covering a wide range of operating conditions.

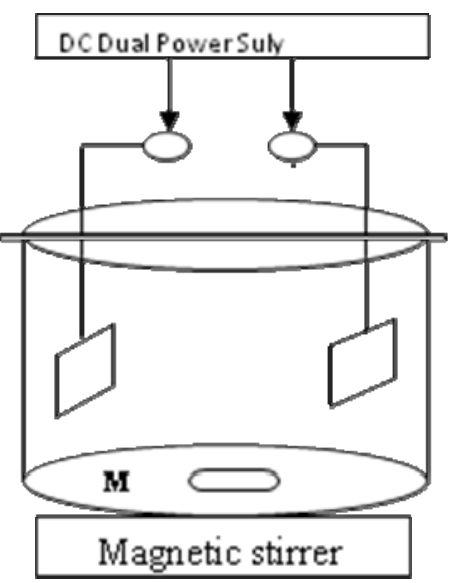

Fig. 1. Schematic Diagram of an Electrochemical Cell (Consisted of Head plate through which stainless steel connected to anode $(+)$ and cathode (-) terminals, $M=$ magnetic bit)

\section{A. Analysis}

The $\mathrm{pH}$ measurements were made on Elico Ion Analyser (LI 126). The chemical oxidation demand of the effluent sample was determined by closed reflux method, using COD digestion apparatus Model ET 108, Lovibond. The absorption spectra of the samples were recorded on Elico scanning mini spectrophotometer (SL 177), recording the spectra over $340 \mathrm{~nm}$ to $1000 \mathrm{~nm}$ range. All the reagents were prepared and analyzed for the different characteristics of wastewater as per standard methods for the examination of water and wastewater ${ }^{[1]}$. To estimate the color removal, the disappearance of the absorbance peaks of the solution was monitored. Percent of color removal in terms of absorbance measured at a fixed wavelength was calculated as follows:

$$
a b s(\%)=\frac{a b s(i)-a b s(t)}{a b s(i)} \times 100
$$

where, $a b s(\%)=$ Absorbance in percentage, $a b s(i)=$ Initial absorbance of the raw sample,

Abs $(t)=$ Absorbance of the treated samples at regular time intervals, $\mathrm{t}$.

\section{B. Methodology}

The efficiency of the electrolytic cell was studied with different current densities (Current density i.e., the current per area of electrode). Each experiment was of batch operation with duration of $180 \mathrm{~min}$. For every 30 minutes samples were drawn and COD, BOD, Color were measured. Before each run electrodes were rinsed with tap-water, dried at $103{ }^{\circ} \mathrm{C}$ cooled and weighed. At the end of each run, the electrodes were washed thoroughly with water to remove any solid residues on the surface, dried and reweighed. When too large current is used, there is a high chance of wasting electrical energy in heating up the water. More importantly, a too large current density would result in a significant decrease in current efficiency ${ }^{5}$. For the present study current densities of $12 \mathrm{~A} / \mathrm{m}^{2}, 24 \mathrm{~A} / \mathrm{m}^{2}$ and $48 \mathrm{~A} / \mathrm{m}^{2}$ were selected and studied for various parameters.

\section{RESUlTS AND DisCUSSIONS}

The characteristics of the Textile Dye wastewater (TDW) are presented in Table I. It is known from the literature that initial $\mathrm{pH}$ does not have significant effect in the degradation of organic pollutants by indirect electrochemical oxidation. Hence in the present study, the electrochemical degradation experiments for the effluents were conducted without $\mathrm{pH}$ adjustments. In the present study sodium chloride present itself was used as a supporting electrolyte and additional electrolyte was not added. The oxidation of organic compounds present in the effluent is mainly due to the generation of hypochlorite and free chlorine. During this investigation the operating parameters such as current, electrolysis time were varied to explore the effect on COD and color removal. Results showed that higher COD and color reduction occurred at higher charge input and electrolysis time.

\begin{tabular}{cc} 
TABLE I: CHARACTERISTIC OF RAW TEXTILE DYE WASTEWATER & Typical Values \\
\hline \hline Parameters & 9.2 \\
pH & 1244 \\
Total Solids & 541 \\
TDS & 28 \\
TSS & 660 \\
TVS & 440 \\
Alkalinity & 307 \\
Chlorides & 307 \\
BOD & 3162 \\
COD & 0.10 \\
BOD/COD
\end{tabular}

(Except $\mathrm{pH}$ and BOD/COD all the parameters in $\mathrm{mg} / \mathrm{L}$ )

\section{A. Chemical Oxygen Demand}

The variation of COD with electrolysis time for different current densities is presented in Fig. 2. It can be ascertained that from Fig. 2, COD decreases with increasing electrolysis time. The trend of COD reduction with electrolysis time remains same for all the current densities adopted in the present investigation. Also rate of COD reduction increases with increasing current density. Reference [5] reported, COD reduction for different current densities varying from 1 to 5 $\mathrm{A} / \mathrm{m}^{2}$, COD reduction increased for a max current density of 5 $\mathrm{A} / \mathrm{m}^{2}$. When the current density is high, significant decrease 
in the current efficiency is expected from the production of oxygen where Current efficiency $\mathrm{CE}$, the ratio of current consumed in producing a target product to that of total consumption.

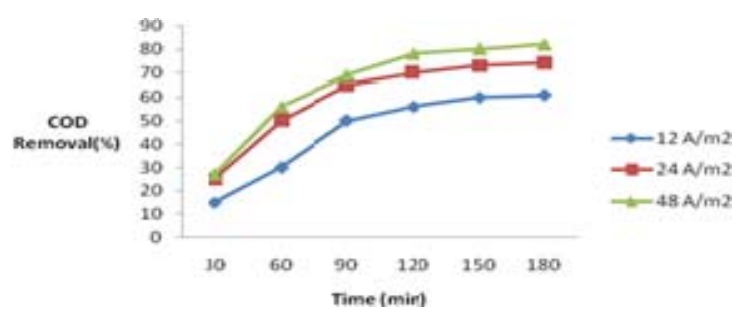

Fig. 2. Percentage Removal of COD at Different Current Densities

\section{B. Color}

The color removal is of great interest because color is considered the most important persisting polluting parameter of TDW. Fig. 3 shows the reduction of color by absorbance with spectrophotometer under various experimental conditions. The rate of color removal increases with increasing current density. This is consistent with Faraday's law according to which the hypochlorite content increases with current density. The removal of color was increased with increasing current density of $\max 48 \mathrm{~A} / \mathrm{m}^{2}$.

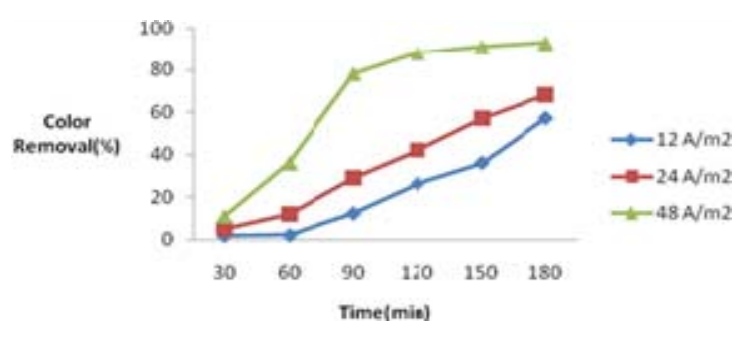

Fig. 3. Percentage Removal of Color at Different Current Densities.

\section{Biochemical Oxygen Demand [BOD]}

It is observed that BOD has increased during the course of reaction as shown in Fig. 4. The increase in BOD concentration is attributed to the fact that some of the organics may have broken down into smaller fragments, which are more biodegradable than the parent compounds.

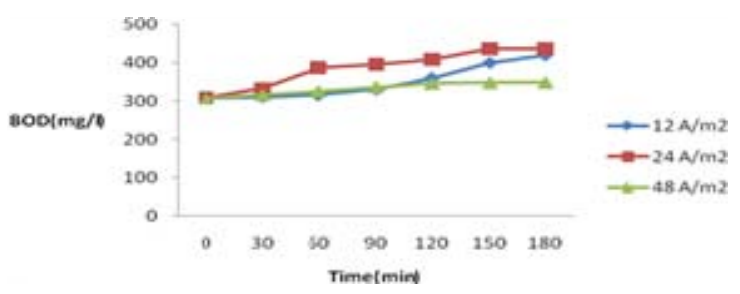

Fig. 4. Variation in BOD at Different Current Densities.

\section{BOD/COD ratio}

It is observed that increase in $\mathrm{BOD} / \mathrm{COD}$ ratio is an indicator of biodegradability with increase in electrolysis duration. The BOD/COD ratio for TDW is about 0.58. Fig. 5 shows that during electrolysis the $\mathrm{BOD} / \mathrm{COD}$ ratio has been increased. Thus for $12 \mathrm{~A} / \mathrm{m}^{2}, 24 \mathrm{~A} / \mathrm{m}^{2}$ and $48 \mathrm{~A} / \mathrm{m}^{2}$ of current densities increase in $\mathrm{BOD} / \mathrm{COD}$ ratio was $0.30,0.43$ and 0.58 respectively.

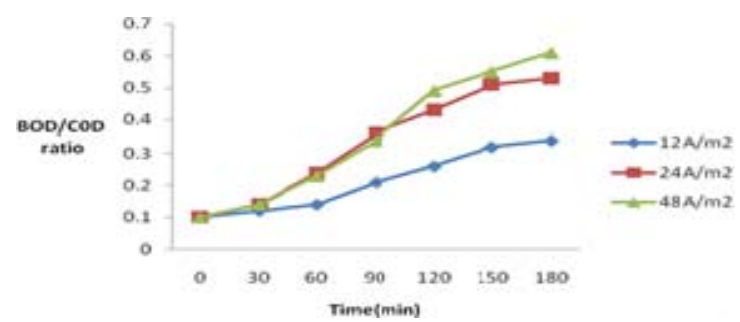

Fig. 5. Variation of BOD/COD Ratio at Different Current Densities.

\section{E. $p H$}

It has been established that the influent $\mathrm{pH}$ is an important operating factor influencing the performance of electrochemical process ${ }^{[5]}$. The effluent $\mathrm{pH}$ would increase for acidic influent but decrease for alkaline influent. This is one of the advantages of this process. The increase of $\mathrm{pH}$ at acidic condition was attributed to hydrogen evolution at cathodes. But besides hydrogen evolution, the formation of $\mathrm{OH}^{-}$ions near the anode would release $\mathrm{H}^{+}$leading to decrease of $\mathrm{pH}$. In addition, there is also oxygen evolution reaction leading to $\mathrm{pH}$ decrease. As for the $\mathrm{pH}$ decrease at alkaline conditions, it can be the result of formation of hydroxide precipitates with other cations. From the Fig. 6 it can be observed that for different current applied, $\mathrm{pH}$ was decreased to $8.564,9.168$ and 8.965 respectively.

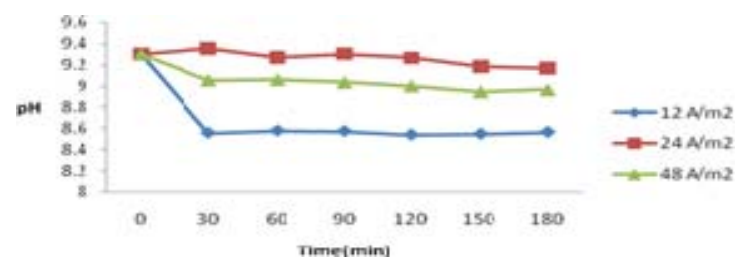

Fig. 6. Variation of $\mathrm{pH}$ at different Current Densities

\section{F. Temperature}

The variation of Temperature with electrolysis time for different current densities is shown in Fig. 7. It was observed that the temperature rose in the range of $2-3^{\circ} \mathrm{C}$ from the initial values. This may be due to the electrolytic dissociation (Arrhenius Ionic Theory) or migration of ions towards the oppositely charged electrodes which constitutes the flow of electric current in the solution. Increase in temperature increases the decolonization rate and COD removal.

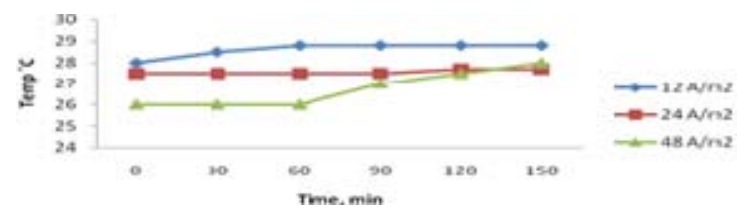

Fig. 7. Variation of Temperature at Different Current Densities 


\section{G. COD Remoal Rate and Energy Consumption}

The efficiency of SS as anode and energy consumption at various current densities is presented in Table II. The anode efficiency has been calculated in $\mathrm{kg}$ of COD removed per hour ampere and per square meter $\left(\mathrm{kg} \mathrm{COD} / \mathrm{h} / \mathrm{A} / \mathrm{m}^{2}\right)$. The energy consumption per $\mathrm{kg}$ of COD removal at the lowest current density is about 296.3 and $1676 \mathrm{Wh}$, for higher current density. Application of higher current densities actually decreases the anode efficiency and increases the energy consumed per $\mathrm{kg}$ of COD removed.

TABLE II: THE COD REMOVAL RATE AND ENERGY CONSUMPTION

\begin{tabular}{|c|c|c|c|}
\hline $\begin{array}{l}\text { Current Density } \\
\mathrm{A} / \mathrm{m}^{2}\end{array}$ & $\begin{array}{l}\text { Voltage } \\
\text { V }\end{array}$ & $\begin{array}{l}\text { COD Removal } \\
\text { Rate, } \mathrm{Kg} \\
\mathrm{COD} / \mathrm{h} / \mathrm{A} / \mathrm{m}^{2}\end{array}$ & $\begin{array}{l}\text { Energy } \\
\text { Consumption } \\
\text { Wh/Kg COD }\end{array}$ \\
\hline 12 & 3.45 & 4.66 & 296.3 \\
\hline 24 & 4.58 & 2.82 & 649 \\
\hline 48 & 6.66 & 1.59 & 1676 \\
\hline
\end{tabular}

\section{H. Kinetics of Reaction}

In the indirect electrochemical oxidation process, the COD removal rate is proportional to the concentration of the organic compound (pollutant) and to the chlorine/hypochlorite concentration because the indirect oxidation is mediated by chlorine/hypochlorite. Therefore, the kinetic for COD removal is

$$
-\frac{d}{d t}(C O D)=k(C O D)(C l 2)
$$

Electrochemical treatment involves the application of an electrical current to the effluent, to convert chloride to chlorine and hypochlorite. The chlorine and hypochlorite will oxidize the organic compound and then get reduced to a chloride ion. The process is then repeated in a catalytic fashion. Therefore, the concentration of chlorine/hypochlorite during the electrolysis is assumed to be a constant and equation can be written as a pseudo first-order kinetic equation.

$$
-\frac{d}{d t}(C O D)=k^{\prime}(C O D)
$$

The log plots of the COD concentration curves show the plot of the rate expression;

$$
\begin{aligned}
& \ln \frac{C O D(t)}{C O D(0)}=-k^{\prime} t \quad \text { or } \\
& \ln \frac{C t}{C 0}=-k^{\prime} t
\end{aligned}
$$

The slope of the plot of $\ln \mathrm{C}_{\mathrm{t}} / \mathrm{C}_{0}$ versus time gives the value of the rate constant $\mathrm{k}^{\prime}, \mathrm{min}^{-1}$. Here, $\mathrm{C}_{0}$ is the initial COD of the effluents in $\mathrm{mg} / \mathrm{L}$ and $\mathrm{C}_{\mathrm{t}}$ is the COD value at time $\mathrm{t}$. Table III provides the respective $r^{2}$ values for COD removal at different current densities.

TABLE III: THE RATE CONSTANT FOR DIFFERENT CURRENT APPLIED

\begin{tabular}{lll}
\hline \hline Current Applied & Current Density, & $\mathrm{r}^{2}$ \\
$\mathrm{~A}$ & $\mathrm{~A} / \mathrm{m}^{2}$ & \\
\hline 0.03 & 12 & 0.445 \\
0.06 & 24 & 0.989 \\
0.12 & 48 & 0.978 \\
\hline \hline
\end{tabular}

\section{CONCLUSION}

In the present investigation electrochemical method has been found to be effective in treating TDW. At a current density of $48 \mathrm{~A} / \mathrm{m}^{2}$, maximum color removal of $77 \%$, COD reduction of $71 \%$ and increase in $\mathrm{BOD} / \mathrm{COD}$ ratio from 0.1 to 0.58 was achieved. Also higher current density increased the energy consumption and removal rate of pollutants. In the present study a current density of $48 \mathrm{~A} / \mathrm{m}^{2}$ was found to be optimum w.r.t. COD and color removal at an ideal time of 120 min in which about $78 \%$ of COD amd $88 \%$ of color removal has been achieved. Hence, it can be concluded that electrochemical treatment is suitable to treat this electrolyte as a pretreatment technology.

\section{ACKNOWLEDGMENT}

The authors are grateful to Bangalore University for the sanction of grant under Young Research Brigade Programme to Smt. Rekha H B. that enabled her to utilize the fellowship for research work.

\section{REFERENCES}

[1] APHA, Standard methods for the examination of water and wastewater, $20^{\text {th }}$ edition. Americal Public Health Association, Washington, D.C, 1998.

[2] Cerqueira A, Russo C, Marques M R C, "Electroflocculation for textile wastewater treatment", J.Chem Eng., 26 (4), 2009.

[3] Chuanping Feng, Norio Sugiura, Satoru Shimada, Takaaki Maekawa, " Development of a high performance electrochemical wastewater treatment system", Journal of Hazardous Materials, B103, pp. 65-78,2003.

[4] Daneshvar N, Khataee A R, Ghadim A R A, Rasoulifard, M H, "Decolorization of c.i. acid yellow 23 solution by electrocoagulation process: investigation of operational parameters and evaluation of specific electrical energy consumption (SEEC)", J of Haz Mat, 148, 2007.

[5] Guohua Chen,"Electrochemical technologies in wastewater treatment". Separation And Purification Technology, vol 38, pp. 11-41, 2004.

[6] J Hussain, I Hussain, and M Arif. "Characterization of textile wastewater", Journal of Industrial Pollution Control, Vol. 20(1), pp.137-144, 2004.

[7] Karuppan Muthukumar and P Shunmuga Sundaram, Treatment of textile dye wastewater by using an electrochemical bipolar disc stack reactor. J of chemical technology and Biotechnology, 79:1135-1141, 2004.

[8] N Mohan, Balasubramanian, and V Subramanian. "Electrochemical Treatment of Simulated Textile Effluent", Chem Eng. Technol, Vol 24, No.7, pp.749-753, 2001.

[9] Vlyssides A G, Loizidou M, Karlis P K, Zorpas A A, "Electrochemical oxidation of a textile dye wastewater using a Pt/Ti electrode", J. Haz Mat, B70, pp. 41-52, 1999.

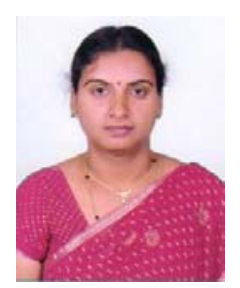

Rekha H B. was born in Mandya, Karnataka, India. Academic Qualifications: B.E, M.Tech (Environmental Engineering). Previously worked as a Lecturer in the Department of Environmental Engineering, Vidyavardhaka College of Engineering, Mysore, India. Presently working as Assistant Professor, Department of Civil Engineering, University Visvesvaraya College of Engineering, Bangalore University, Bangalore-56, India. She has total 6 years of R \& D and teaching experience and one year of Industrial Experience. 